\title{
artículos
}

\section{Templum sive Theatrum. Recursos escénicos y espacio sacro}

\author{
Rubén López Conde \\ Universidad de Jaén
}

RESUMEN

Algunos reputados estudiosos han advertido del abuso que supone emplear indistintamente los términos barroco y escenografía. Sin embargo, con ser cierta esta observación, el teatro y sus modos llegaron a desbordar el específico espacio de la representación para percutir en otras parcelas de la cotidianidad y las artes del periodo, encontrando en el recinto sagrado un campo particularmente fértil para el cultivo de su falaz semilla.

PALABRAS CLAVE: teatro/ templo/ escenografía/ tramoya/ perspectiva/ ingeniero/ Cosimo Lotti/ autómata/ retablo/ tabernáculo/ Monumento/ Cuarenta Horas.

Templum sive Theatrum. Stage resources and sacred space

ABSTRACT

Some renowned scholars have warned against the abusive use of the terms baroque and scenography as synonyms. However, although this is a correct observation, Theatre and its ways exceeded their specific borders to have significant effects on other areas of everyday life and Art in that period, finding in the sacred places a fertile ground to cultivate its treacherous seed.

KEY WORDS: theatre/temple/ scenography/ stage machinery/ perspective/ engineer/ Cosimo Lotti/ automaton/ altarpiece/ tabernacle/ Monument/ Forty Hours.

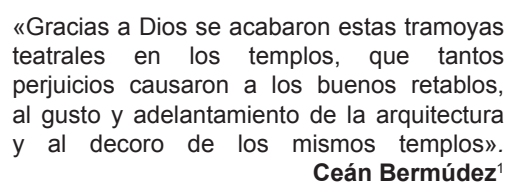

Proemio.

La naturaleza teatral del complejo universo barroco fue tempranamente advertida por pensadores e investigadores. Muchos fueron los que penetraron (y aún en la actualidad siguen haciéndolo) por entre sus complejas formas e implicaciones, anotando no sólo la pluralidad de manifestaciones que habían exhibido su falaz envoltura, sino también el carácter instrumental que su explotación dirigida había llegado a suponer.

* LÓPEZ CONDE, Rubén: "Templum sive Theatrum. Recursos escénicos y espacio sacro”, en Boletín de Arte $n^{\circ}$ 32-33, Departamento de Historia del Arte, Universidad de Málaga, 2011-2012, págs. 363-385. Fecha de recepción: Febrero de 2010.

1 CEÁN BEMUDEZ, J. A., Diccionario histórico de los más ilustres profesores de las Bellas Artes en España,

T. 3, Madrid, 1800 , p. 82 
En nuestro país, fue el profesor Emilio Orozco² quien más decididamente insistió en el meditado desbordamiento que de lo teatral había sufrido la entera vida barroca, consagrando buena parte de sus celebrados estudios a este singular y epidémico fenómeno y desglosando con lúcida perspicacia gran parte de sus heterogéneas expresiones. Entre otras parcelas así afectadas se refirió a la dramatización de la función religiosa, reconociendo la artificiosa práctica de oficiantes y predicadores; práctica paradójicamente desplegada en uno de sus más primitivos espacios escénicos, el templo, ahora impregnado de un renovado mimetismo dramático y servido con hiperbólica escenotecnia ${ }^{3}$. Una teatralización a la que acudieron en fructífera simbiosis la más moderna práctica artística y los preceptos emanados de Trento (sobre el principal sustento del valor pedagógico atribuido a las imágenes, con evidentes repercusiones en la conformación y desarrollo de la cultura visual del período, y mediante el reforzamiento del culto a la Eucaristía y los Santos, hecho que afectará no sólo a las prácticas celebrativas de la época, punto de confluencia de las tres variables de nuestra ecuación: lo sagrado, lo artístico y lo teatral, sino también al surgimiento y desarrollo de una complicada maquinaria arquitectónica, vinculada a estas nuevas formas sublimadas del culto y que condensará la mayor parte de los efectos escénicos del espacio sacro, a saber: altares, retablos y tabernáculos), deviniendo así un conjunto elocuente de altos valores escenográficos. Huelga decir que esta mixtura encontró un poderoso aglutinador en el extraordinario desarrollo de los multiformes hechos teatral y festivo.

En este sentido, la vasta senda abierta por el profesor Orozco ha sido continuada, no sin retrocesos, por otros muchos estudiosos del teatro y las artes del período. Y es aquí que conviene aludir a las aportaciones realizadas de dos reputados investigadores de ambas esferas del conocimiento: los profesores Díez Borque $^{4}$ y Rodríguez G. de Ceballos ${ }^{5}$.

El primero, avisado del reduccionismo que suponía para el conocimiento de la bullente y compleja realidad teatral del Siglo de Oro un estudio exclusivista de los géneros mayores, un acercamiento purista al análisis del espectáculo teatral, «la preocupación por la letra [...] más que por la realidad escénica», señaló la necesidad de hacer extensivo su examen a nuevas (por cuanto apenas exploradas) orbitas de teatralidad; estas, concéntricas y decrecientes en intensidad teatral, abarcarían una miríada de ámbitos, géneros y representaciones, ocupando no pocas de sus

2 El Teatro y la Teatralidad del Barroco, Barcelona, Planeta, 1969; y «Sobre la teatralización del templo y la función religiosa en el Barroco: el predicador y el comediante», Cuadernos para la Investigación de la Literatura Hispánica, 2-3 (1980), pp. 171-188.

3 De hecho, es posible encontrar dispositivos escenográficos -aun en sus formas más elementales- ya en época tardomedieval: autómatas, imágenes articuladas o ciertos mecanismos de tramoya aérea.

4 «Órbitas de teatralidad y géneros fronterizos en la dramaturgia del siglo XVII», Criticón, 42 (1998), pp. 103-124.

5 «Espacio sacro teatralizado: el influjo de las técnicas escénicas en el retablo barroco», en DE LA GRANJA, A. et alii (eds.), En torno al teatro del Siglo de Oro. Actas de las VII-VIII Jornadas, Almería, Instituto de Estudios Almerienses, 1992, pp. 137-154. 
categorías ciertas dramatizaciones y liturgias habidas en iglesias y conventos (más o menos alejadas del núcleo de intensidad plena, ocupado por los géneros canónicos), servidas en su praxis de formas y recursos enteramente teatrales.

Desde la historiografía del arte, ha sido el académico Rodríguez G. de Ceballos el que parece haber mostrado una mayor inclinación por el estudio de estas parcelas de intercomunicación entre sendas realidades (teatral y artística, pero también religiosa), escudriñando bien los complejos mecanismos de escenificación del teatro cortesano aurisecular, bien la específica personalidad artística de sus todavía mal conocidos creadores, los ingenieros-escenógrafos, bien la concreta irradiación de sus técnicas al específico ámbito de los templos. En la materia que aquí nos concierne, la presencia de dispositivos teatrales en los espacios sagrados, su análisis ha quedado centrado en las formidables máquinas retablísticas del Barroco español (sobre las que igualmente se han referido Martín González y Bonet Blanco $)^{6}$, reparando sutilmente en la polarización de sus efectos escenográficos en torno a sagrarios, tabernáculos y manifestadores eucarísticos (que obedecerían a la mentada exaltación promovida desde Trento): la aplicación focalizada de efectos lumínicos, la inclusión de bastidores con perspectivas fingidas, el empleo de telones de boca o la instalación de complejos mecanismos de tramoya harían del recinto sagrado un espacio para la enajenación de los sentidos, ilusorio y sobrenatural, distanciado de la vulgar y cruel realidad cotidiana, concentrando el interés de la admirada feligresía en torno a los misterios de la religión y sirviendo con formidable eficacia a la vocación pedagógica afirmada en el Concilio.

Pero las relaciones entre los espacios sacro y escénico no acaban aquí: la singular presencia de autómatas y figuras articuladas, ora participando de ocasionales piezas escénicas, ora formando parte del aparato permanente de los templos (autómatas de reloj; Cristos articulados); el recurso continuado a la perspectiva y otros efectos ilusionísticos (que comparten artes plásticas y teatro); la fijación plástica de sólitos efectos escenográficos; la gestualidad y caracterización de las imágenes sagradas; la transmutación decorativa del espacio, la introducción de un fastuoso aparataje efímero o la representación de piezas escénicas en los espacios de culto (con ocasión de conmemoraciones festivas; e incluso despojando de sus funciones primordiales a los espacios consagrados, caso de algunas de las Ermitas del Buen Retiro); el apelo común a los sentidos (luces tamizadas, aromas, acompañamiento coral y musical); el mimetismo bidireccional de ciertos dispositivos arquitectónicos (arcos de embocadura, púlpitos, palcos, tribunas y galerías; a este respecto, conviene llamar igualmente la atención -invirtiendo los términos de nuestra ecuación-, sobre la efectiva contaminación formal y terminológica que experimentan las primeras tentativas humanistas de reconstrucción del teatro y la escena clásicos

6 MARTÍN GONZÁLEZ, J. J., «Avance de un tipología del retablo español», Imafronte, 3 , 4 y 5 (1987), pp 111-155; y «Sagrario y Manifestador en el retablo barroco español», Imafronte, 12 (1998), pp. 25-50. BONET BLANCO, M. C., «El retablo barroco: escenografía e imagen», en CAMPOS, F. J. (ed.), El Monasterio de El Escorial y la pintura, El Escorial, R. C. U. María Cristina, 2001, pp. 623-642. 
o el sorprendente proyecto leonardesco del Teatro per Udire Messa); o, en definitiva -y como bien advirtió el profesor Orozco-, la organización del espacio del templo con sentido plenamente teatral. Obviamente, sería pura heroicidad desgranar tan complejas cuestiones dentro de las estrictas coordenadas que impone un artículo; razón por la que habré de limitar mi análisis a las escenografías, los mecanismos de tramoya y otros recursos espectaculares explotados en los recintos sagrados. No obstante, dejaré filtrar testimonios que avalen la interpretación de estos espacios desde la perspectiva de su positiva teatralización.

\section{Teatro y Templo.}

Antes de penetrar en el examen de las citadas relaciones, conviene establecer una primera matización que afecta a tres de las variables aquí consideradas: teatro, fiesta y liturgia. El presente análisis se circunscribe con exclusividad a los espacios religiosos, atañe a formas y recursos esencialmente teatrales y no pocas veces se asienta en el apretado calendario festivo barroco; circunstancia ésta que puede suscitar el recelo de los espíritus más rigoristas. Es cierto que -como pertinentemente ha sido señaladoteatro, fiesta [y también liturgia, podemos añadir] poseen en el Barroco características bien definidas, que permiten, quizá por vez primera, la distinción neta de sus espacios privativos: corral, calle y templo. Pero no menos cierto -como ha apuntado Díez Borque-, que existen «puntos de encuentro, lugares de convergencia», que conducen a espacios de indefinición, que sugieren una permeabilidad de fronteras. Siguiendo a este reputado investigador, más allá de las diferencias, existen coincidencias importantes entre sus componentes y modos de realización $n^{7}$. Y es aquí, en estas zonas de indefinición, en estos espacios de convergencia, que se sobrepone el presente trabajo. Su objetivo no es indagar por entre el complejo entramado conceptual de la representación teatral, ni responder a obsesivas e irresolubles cuestiones de preeminencia (más fructífero resulta pensar en una plural y simbiótica cultura visual) ${ }^{8}$, sino ratificar la absoluta validez de éstas y análogas afirmaciones, demostrar, aun sabiendo que no es axiomática la ecuación Barroco igual a Escenografía ${ }^{9}$, que la teatralidad fue un fenómeno global, un hecho multiforme que desbordó el espacio específico de la representación para percutir en las parcelas más diversas de la cotidianidad, convertido así en un aspecto definitorio del período.

7 DÍEZ BORQUE, J. M., «Relaciones de Teatro y Fiesta en el Barroco español», en DíEZ BORQUE, J. M (ed.), Teatro y Fiesta en el Barroco: España e Iberoamérica, Barcelona, Ediciones del Serbal, 1986, pp. 1820.

8 Las interacciones entre disciplinas artísticas, entre manifestaciones culturales son múltiples, y las fronteras de la creación, afortunadamente permeables (en consonancia con la riqueza que presupone el acto creativo). En este orden, parece ilógico pensar en la rotunda autonomía visual y técnica de las disciplinas respecto de sus propios productos (lo que por otro lado puede sugerir pobreza), y evidente suponer aportes de muy diversas extracciones; una permeabilidad que se juzga tanto más evidente cuanto se profundiza en la biografía de los principales responsables de los aparatos escénicos barrocos, los ingenieros-escenógrafos, con capacidades y desempeños que superan largamente la sola representación teatral.

9 RODRÍGUEZ G. CEBALLOS, A., Op. cit., p. 137. 
Acometiendo ya el análisis específico, y a modo de premisa, conviene recordar que la introducción efectiva de mecanismos escenotécnicos en los espacios del templo no principia en el Barroco. Ya desde finales del Medioevo, puede verificarse una continuada presencia de estos dispositivos en los recintos sagrados; presencia generalmente vinculada a ciertos fenómenos espectaculare ${ }^{10}$ habidos con ocasión de las principales festividades del calendario litúrgico. En este sentido, nubes o aracelis (artefacto que permite el desplazamiento vertical de personajes celestiales, dispuestos sobre trapecios y parapetados tras nubes fingidas) o más complejas mandorlas (algunas provistas de iluminación perimetral), pueblan el espacio aéreo de los templos, sirviendo a una escenografía que abunda en el carácter sobrenatural de los personajes y que en esencia viene a coincidir con la empleada para los más fastuosos festejos cívicos ${ }^{11}$. Estas escenografías se completan con la decoración, permanente o efímera, de bóvedas celestes, y con otros artificios de indudable efectismo, caso de las aperturas practicadas en cubiertas para el vertido de pétalos y oropeles o para la liberación de animales (generalmente palomas ${ }^{12}$; y algunas, mecánicas ${ }^{13}$ ), o incluso con el uso ocasional de artefactos pirotécnicos. Del empleo temprano de estos artificios espectaculares en el interior de los templos dan cumplida cuenta el Misteri d'ElX $X^{14}$ o las sacras representaciones italianas (conocidos resultan los ingenios diseñados por Brunelleschi). No es de extrañar pues, habida cuenta de la difusión de estas tramoyas y la vitalidad de las celebraciones cívicas y religiosas, el surgimiento de toda una suerte de artífices especializados, embrión de los afamados ingenieros-escenógrafos del Barroco: machinayres en la Corona de Aragón, maîtres des secrets o feinteurs en Francia e ingegneri en Italia ${ }^{15}$.

10 Teatrales, parateatrales o paralitúrgicos. No es mi objetivo, ni está entre mis capacidades discutir el grado de teatralidad de estos fenómenos. En cualquier caso, remito a la consideración sobre este particular del profesor QUIRANTE SANTACRUZ, L.: «De Les Torres del Serrans a la Seu y viceversa: relaciones entre teatro religioso y entrada reales en la Valencia del siglo XV», en PEDRAZA JIMÉNEZ, F. y GONZÁLEZ CAÑAL, R. (eds.), Los albores del teatro español. Actas de las XVII Jornadas de Teatro Clásico de Almagro, Almagro, Universidad de Castilla-La Mancha, 1994, p. 11, Nota 1.

11 Caso de las entradas reales y coronaciones. En este sentido, resulta elocuente el citado artículo de Luis Quirante; las ejemplares indagaciones en la fiesta pública de la profesora FERRER VALLS, T.: «La fiesta cívica en la ciudad de Valencia en el Siglo XV», en RODRÍGUEZ CUADROS, E. (ed.), Cultura y representación en la Edad Media, Alicante, Instituto Alicantino Juan Gil-Albert, 1994, pp. 145-169; «El espectáculo profano en la Edad Media: espacio escénico y escenografía», en CANET VALLES, J. L. et alii (eds.), Historias y Ficciones. Coloquio sobre literatura del siglo XV, Valencia, Universitat de València, 1992, pp. 307-322; y «El espectáculo de la fe; manifestaciones religiosas de la fiesta pública en el siglo XVI», Criticón, 94-95 (2005), pp. 121-135; o la siempre docta aportación del hispanista J. E. Varey: "Cosmovisión y niveles de acción», en CANET VALLÉS, J. L. (ed.), Teatro y Prácticas Escénicas, Vol. II, Londres, Tamesis, 1986, pp. 50-65.

12 Resulta ilustrativa la disposición contenida en las Constituciones Sinodales de Plasencia de 1534: «Que el día del Espíritu Santo el sacerdote eche paloma y no otra ave, Porque [...] que en lugar de echar paloma, el saçerdote echa pollos [...] Y después de echada por el saçerdote, permitimos que se echen otras aves, las que quisieren, por la solemnidad de la fiesta». Cit. en MENÉNDEZ PELAEZ, J., «Teatro e Iglesia. Las Constituciones Sinodales, documentos para la reconstrucción del teatro religioso en la Edad Media y el Renacimiento español», Archivum, 48-49 (1998-99), Oviedo, p. 298.

13 Como las que describe Varey para las celebraciones de Navidad y Pentecostés en Valencia. Op. cit., pp. 51-52.

14 Ibídem, pp. 52-55.

15 FERRER VALLS, T., Op. cit. (1992), p. 318. 
Pese a las repetidas tentativas de las autoridades eclesiásticas por desterrar del ámbito del templo ciertos hábitos estimados indecorosos ${ }^{16}$ (tocantes a las citadas actividades), muchas de estas celebraciones y su maquinaria perviven en la Edad Moderna, las más de las veces arropadas bajo el manto de la festividad y/o la devoción popular.

Un ejemplo elocuente de esta pervivencia $-y$ se cuentan por cientos- lo constituye el dispositivo prevenido en la iliturgitana Iglesia de San Eufrasio, con ocasión de la traslación festiva de las reliquias de su patrón (1597). Llegado el cortejo al recinto -que durante la procesión había tenido la oportunidad de contemplar gran número de artefactos mecánicos ${ }^{17}$ :

«comenzó a bajarse una nube artificial que estaba pendiente de lo más alto del templo, y desplegándose poco a poco despidió de sí gran cantidad de confitura de toda suerte, y agua de flores, por buena orden, que parecía que llovía agua y granizo, y acabándose de abrir toda, descubrió un San Eufrasio de bulto cercado de Ángeles, vestido de Pontifical...».

Entre otras prácticas sobrevividas, e incluso vivificadas durante el Barroco, cabe primeramente referirse a las poliédricas funciones de Semana Santa; en especial, aquellas protagonizadas por prodigiosas figuras articuladas, que representan, no sin abundancia de parafernalia escénica, episodios de la Pasión y Muerte de Jesucristo: el Desenclavo, el Descendimiento y la Deposición. Entre sus más conocidos intérpretes medievales ${ }^{18}$ pueden cifrarse el segoviano Cristo de los Gascones, el Santo Cristo de Burgos o las tallas articuladas de Palencia, Orense y Finisterre (no obstante la primacía de Cristo, participan también de estas ceremonias Dolorosas articuladas). Prácticas e imágenes que alcanzan extraordinaria resonancia durante el período -como así certifica el formidable número de celebraciones conocidas o las cuantiosas imágenes despachadas por los talleres imagineros ${ }^{19}{ }^{1}$, Ilegando sólo a desaparecer bajo la férula de la Razón ilustrada ${ }^{20}$.

16 MENÉNDEZ PELÁEZ, J., Op. cit.

17 TERRONES ROBLES, A., Vida, Martyrio, Translación, y Milagros de san Euphrasio, Obispo, y Patrón de Andujar..., Granada, 1657, fol. 256r. Han sido corregidas la grafía y puntuación a fin de facilitar la lectura.

18 MARTÍNEZ MARTÍNEZ, M. J., «El Santo Cristo de Burgos y los Cristos Dolorosos articulados», Boletín del Seminario de Estudios de Arte y Arqueología, 69-70 (2003-2004), pp. 207-246. No serían las únicas figuras articuladas de ascendencia medieval que formarían parte de singulares montajes escenográficos, caso de la sevillana Virgen de los Reyes o del Santiago Apóstol que ordenaba a los caballeros en el Monasterio de las Huelgas. CORNEJO VEGA, F., «La escultura animada en el arte español. Evolución y funciones», Laboratorio de Arte, 9 (1996), pp. 239-261; y ARACIL, A., Juego y Artificio. Autómatas y otras ficciones en la cultura del Renacimiento a la llustración, Madrid, Cátedra, 1998, p. 58.

19 Sólo en la pequeña Diócesis de Coria (Cáceres), y durante la primera mitad del siglo XVIII, se demandan más de medio centenar de estas imágenes articuladas: DOMíNGUEZ MORENO, J. M., «La función del Descendimiento en la Diócesis de Coria (Cáceres)», Revista de Folklore, 77 (1987), pp. 147-153. Cfr asimismo: SÁNCHEZ DEL BARRIO, A., "El rito del Descendimiento en la Villa de Olmedo», Revista de Folklore, 127 (1991), pp. 23-26.

20 Gran interés reviste el edicto de prohibición de las funciones del Descendimiento en la Diócesis de Coria (Badajoz), dictado en 1788 por el obispo Diego Martín y Rodríguez. En este caso, a los frecuentes razona- 
Aunque sólo brevemente, conviene detenerse en la espectacular -e ilustrativa a nuestros fines- presentación del Cristo de Burgos ${ }^{21}$, habida en el cenobio de los Agustinos Ermitaños de la citada localidad ${ }^{22}$ :

«Se guardaba en una capilla del claustro [concebida para su exhibición y con capacidad para más de cien personas] iluminada por ocho candelabros y cuarenta y ocho lámparas [...] Para contemplar la imagen había que retirar dos de los tres cortinajes [que lo ocultaban], el primero con la imagen dibujada de Cristo [a la manera de los telones de boca, que incluían referencias iconográficas a la pieza que había de representarse], el segundo de seda roja y el tercero de gasa muy fina y transparente a través del cual se veía [...] Al mismo tiempo que se descorrían las cortinas sonaban las campanas y antes de que se viese la imagen se encendían todos los cirios...».

El empleo de cortinajes en el templo, con una función solemne o sorprendente, es práctica habitual ya en la Edad Media; pero sólo en el Barroco alcanza sus más altas cotas de desarrollo. Un recurso reiterado de predicadores, que en el clímax de su discurso y con grave afectación dramática, descorren estos sencillos velos para dejar a la contemplación imágenes aleccionadoras, descriptivas o de fuerte impacto emocional. Uso que presenta claras concomitancias con la práctica teatral coetánea (las conocidas apariencias). Como ha establecido Aparicio Maydeu, «para generar el vértigo de la fe, la oratoria sagrada acude a fórmulas dramáticas con las que el público del corral de comedias estaba familiarizado. Y la apariencia como golpe de efecto escénico final es una de ellas» ${ }^{23}$. No deben extrañar pues los quejumbrosos versos del poeta recogidos por Josef de Alfay ${ }^{24}$ :

¡Oh, sacro oficio! Ya profanado en todo, es comedia el sermón, teatro el templo, farsante el que predica, autor el diablo.

mientos ilustrados (falta de decoro y rechazo de la superstición), se sobreponen argumentos de índole estética, fácilmente enlazables con la prologal cita de Ceán Bermúdez: «[...] a fuerza de artifizios y Esterioridades, como son dar rezios golpes con el martillo para desenclavar el Cadáver del Sr. por la tramoia (así se debe llamar). Que se usa en algunos pueblos de subir y bajar con un cordel las manos de la Ymagn. de $\mathrm{N}^{\mathrm{a}} \mathrm{S}^{\mathrm{a}}$ de la Soledad para limpiar los ojos y Recivir la corona [...] y otras imbenziones ajenas a la seriedad con que se debe celebrar este tierno paso: que si las viese vn infiel ciertamente se burlaria de nuestro culto y religion». Cit. DOMÍNGUEZ MORENO, J. M., Op. cit.

21 Dotado de un truculento naturalismo, sin duda anticipador del Barroco, que debió cooperar en la verosimilitud de estas representaciones. Para una completa descripción de éste y otros interesantes particulares, remito a MARTÍNEZ MARTÍNEZ, M. J., Op. cit.

22 Ibídem., pp. 219-220.

23 APARICIO MAYDEU, J., "Calderón y el "Banquete de los Sentidos". De la escenografía de las apoteosis en la comedia religiosa del siglo XVII», Grama y Cal, 1 (1995), pp. 28-29. Las prácticas de oficiantes y predicadores han sido estudiadas in extenso por Orozco Díaz. Ver Nota 1.

24 Cit. MARTÍN MÁRQUEZ, A., La celebración de las Cuarenta Horas en Zamora en los siglos XVII y XVIII, Zamora, Edición Festival Internacional de Música "Pórtico de Zamora", 2007, p. 33. 
Por otro lado, parece obvio el decidido efecto teatral que cortinajes, pabellones y otras colgaduras fingidas imprimen a la superficie parietal de los templos, ora recogidos por ángeles retozantes, que descubren al fiel-espectador objetos, personajes y escenas, ora cerrados a la manera de telones de boca y cortinas de apariencias.

Llegados a este punto conviene referirse a las figuras autómatas, emparentadas con las anteriores por razón del movimiento y su audaz naturalismo (sentido en que cabe interpretar la recreación de las cualidades de lo vivo ${ }^{25}$, pero también por responder a dos de los más preciados valores barrocos, el ingenio y la conmoción, motores -estos y aquellos- de la estética del período. Asiduos de los escenarios cortesanos (recuérdense las figuras obradas por Cosimo Lotti para La selva sin amor, que, a decir de Ceán ${ }^{26}$, cruzaban el Puente de Segovia «representando con mucha gracia y verdad a las que transitan por él ordinariamente»; o el portentoso Atlante diseñado por Baccio del Bianco para la representación de Las Fortunas de Andrómeda y Perseo) y los corrales de comedias (caso de los retablos mecánicos o mundonuevos, empleados para la representación de episodios de la vida de Jesucristo $)^{27}$, su presencia en los templos no resulta infrecuente. Con un ascendente de nuevo medieval, y ligados principalmente a la medida del tiempo, multitud de jaquemarts (autómatas campaneros) y otras figuras y agrupaciones semovientes (que en no pocos casos ejecutan complejas y variadas representaciones; a la manera de los Teatros concebidos por Herón de Alejandría o de los propuestos por Gio-Battista Aleotti $)^{28}$, se instalan en torres y relojes -aunque también en interiores- de algunas conocidas iglesias europeas ${ }^{29}$. De entre los ejemplares españoles, es notable el reloj interior de la Catedral de Burgos, ocupado por los célebres Papamoscas y Martinillo. De sus pretensiones escénicas nos informa la reunión de capitulares que decidió su construcción (1519; aunque finalmente el proyecto sufriría modificaciones) $)^{30}$ :

25 CORNEJO VEGA, J., Op. cit., p. 243

26 CEÁN BERMÚDEZ, J. A., Op. cit., T. 3, p. 52, Voz LOTTI.

27 Nótese que reciben esta denominación por razón de su semejanza estructural con sus homónimos de altar; similitud que asimismo verifican los vestuarios de los corrales. Por otro lado, la vinculación de estos con el universo de los títeres y la adopción de una temática religiosa, les permite eludir las prohibiciones de Cuaresma. VAREY, J. E., «Representaciones de títeres en teatros públicos y palaciego: 1211-1760», Revista de Filología Española, 38 (1954), pp. 181-182.

28 ARACIL, A., Op. cit., Cap. I. Además de traductor del teórico alejandrino, la actividad del arquitecto y escenógrafo Giovan Battista Aleotti resulta de gran trascendencia para la Historia del Teatro. Responsable del desaparecido Teatro de los Intrépidos de Ferrara (1606), al que tradicionalmente se atribuye la incorporación primera de bastidores laterales, y del Farnese de Parma (1618), obra maestra de la arquitectura teatral barroca, que introduce importantes novedades respecto de las construcciones precedentes, emplea por vez primera el arco de proscenio (al menos sobre estructura estable; existen ejemplos cinquecentescos que aplican este elemento a construcciones efímeras; Cfr. CARANDINI, S., Teatro e Specttacolo nel Seicento, Roma-Bari, Laterza, 2003, p. 200), y el telón de boca. Asimismo: RUANO DE LA HAZA, J. M., «La Escena», en DÍEZ BORQUE, J. M. (ed.), Teatro y Fiesta del Siglo de Oro en tierras europeas de los Austrias. Madrid, SEACEX, 2003, p. 253.

29 ARACIL, A., Op. cit., pp. 62-66.

30 Ibídem, p. 64. La cursiva es mía. 
«Facer una invención de un tardón, que era un fraile rezando en su libro y un mochacho con él, y cuando hubiese de dar el relox, le daba el fraile un coscorrón con un palo, e salia un rétulo que decia, "despierta é cuenta", e que el mochacho despierta y se pone á contar. E asimesmo otra invención, que á cada hora que hobiere de dar se represente un misterio de la Pasión, cada vez de otra manera. Los dichos señores dijeron que se hiciese el Tardón».

Referencia ésta que cabe relacionar con la conocida Pasión de tramoyas concebida por Bianco para la madrileña Iglesia del Hospital de los Italianos en abril de 165631; recinto en el que su compatriota y predecesor Cosimo Lotti también hubo de imprimir, como bien podrá comprobarse, su teatral huella.

Ahondando en esta línea, las celebraciones que la ciudad de Granada consagró a la Inmaculada Concepción en 1651, proporcionan un ejemplo extremo de la presencia de estos automatismos en los recintos sagrados. Dentro del complejo y variado aparato empleado para la acomodación festiva del Convento de San Francisco, se dispuso en el centro del claustro un enorme monte horadado por grutas, encimado por un castillo almenado; ocupaban la completa estructura gran diversidad de figuraciones, las más de las veces semovientes: entre otras, un leñador que intentaba talar un ciprés; una ruydosa fragua en la que varios oficiales golpeaban acompasadamente un yunque ${ }^{32}$; o las representaciones del Sueño de Jacob, con lúzidas esquadras de ángeles desplazándose por la escala soñada, y del Arca de Noé, a la que accedían continuadamente toda suerte de bestias. La crónica concluye con la descripción del artificio ${ }^{33}$ :

«En la misma pasta y materia de la peña o monte, estaba una oculta puerta, por donde sin ser visto, entraba un hermano donado, y con una cigüeña sola, que movía distintas ruedas, cuerdas y otros artificios [...] disponía el movimiento de las seis propuestas invenciones [...] siéndolo grande, que de un oculto movimiento sólo hecho en las entrañas de un peñasco, se produjesen tantos milagrosamente manifiestos a todos».

31 «En el Hospital de los Italianos ha hecho el Bacho toda la Pasión de Cristo Señor nuestro, de tramoyas, que ha espantado la Corte. Jueves, al amanecer, hizo la Oración del Huerto, y luego el Prendimiento. A las siete los azotes y el Eccehomo; á las nueve el ponerle en la Cruz, y con él á los ladrones; á las cuatro de la tarde el quitarle de ella y el entierro, y mañana ha de hacer la Resurrección, y todo esto de personas de bulto, que ha espantado al mundo, particularmente el clavarle en la Cruz, y el subir por dos escaleras á desclavarle de ella, como si fueran verdaderamente hombres. Hoy se dice lo ve todo el Rey de rebozo. No me espanto, que es cosa grande. Halo hecho por su devoción, sin haber llevado interés ninguno, por ser el Hospital de su patria». Cit. BARRIONUEVO, J., Avisos (1654-1658), T. II, Madrid, 1893, pp. 365-366.

32 Reproducirían una conocida propuesta de Aleotti. Ver: Nota 27. Por otro lado, algunos de estos grupos resultan relativamente frecuentes en el aparato lúdico de muchas festividades. Cfr. MÉNDEZ RODRÍGUEZ, L. «Sobre autómatas en las fiestas del Corpus Christi en 1677», Laboratorio de Arte, 18 (2005), p. 209-220.

33 PARACUELLOS CABEZA DE VACA, L., Elogios a MA Santíssima consagrolos en suntuosas celebridades devotamente Granada..., Granada, 1651, pp. 53-57. 
Con motivo de esta celebración, se levantó además un completo teatro en el cuerpo de la iglesia ${ }^{34}$ para representación de autos (el Corpus había tenido lugar pocos días antes), «que siendo como fueron del misterio que se celebraba, no fue indecencia al lugar y sitio, regocijo tan debido». De un lado se dispuso un gran tablado, organizado en dos cuerpos, uno para escenario y otro para vestuario; éste «de siete varas en alto, [con] nichos, bofetones, y tramoyas, y poco más abajo se descubrían unos tronos, y unas debanaderas, y otros instrumentos, que la representación de los Autos pedía». De otro, se habilitó un graderío, con seis órdenes de asientos. En el espacio que mediaba entre sendas estructuras se dispusieron «muchos escaños y bancos para personas de lustre y autoridad». Para acomodo de la concurrencia, se desembarazó asimismo el resto de la iglesia. Los más condecorados encontraron privilegiado palco y decente retiro en el coro y tribunas de la iglesia, restauradas a este fin, «echándoles a todas sus puertas y ventanajes, cerraduras, y herraje de nuevo». El coro alto quedó reservado a autoridades locales, adornado «con prevención de colgaduras y sillas».

Nótese el similar servicio que ofrecen estos dispositivos arquitectónicos, que fueron concebidos con idéntica vocación visual; en algunos casos, como en los coros y tribunas de las comunidades femeninas, la consonancia con la arquitectura teatral parece más evidente: éstos, provistos de cerradas celosías, apelan vivamente a las conocidas tertulias de los corrales, donde clérigos y nobles furtivos acudían a ver sin ser vistos.

Hasta ahora me he referido a ciertos dispositivos que, pese a gozar de plena vigencia en el Barroco, hunden sus raíces en la tradición tardomedieval. En adelante aludiré a aquellos elementos que adquieren rotunda carta de naturaleza en la Edad Moderna (aunque en ocasiones pueda argüirse una rudimentaria filiación o aparezcan combinados con algunos de los recursos aludidos).

Introducidos pues en plena Edad Moderna, los elementos que más abiertamente abrazaron la escenotecnia teatral fueron aquellos vinculados con la exhibición eucarística. De este modo, sagrarios, tabernáculos y manifestadores (y sus soportes retablísiticos) concentraron buena parte de los recursos escénicos explotados en el templo. Sin embargo, no fueron los únicos; la exposición festiva o extraordinaria del cuerpo sacramentado de Cristo se erigió campo especialmente abonado para la transmutación escenográfica del espacio sagrado: de este modo, los fastuosos monumentos de Semana Santa o los espectaculares montajes habidos con motivo de la celebración de las Cuarentas Horas, desarrollaron fórmulas muy próximas a las empleadas en el teatro cortesano (no en vano algunos reputados artistas y escenógrafos participaron en la elaboración de estos aparatos: en Italia, Parigi, Bernini, Cortona, Rainaldi; y en España, Cosimo Lotti y Baccio del Bianco $)^{35}$. A este efectista

4 Ibidem, p. 47 y ss.

35 La referencia a la participación de Cosimo Lotti en estos montajes, una vez establecido en nuestro país, 
tratamiento y desarrollo afluyeron razones de índole histórica, doctrinal y estética; la principal, el impulso otorgado por Trento al culto eucarístico, con repercusiones evidentes en las artes plásticas y el teatro (autos sacramentales).

En cuanto al primer grupo (retablo-tramoya), ha sido estudiado in extenso, entre otros, por los profesores Rodríguez G. Ceballos y Martín González ${ }^{36}$. Y aunque la cortedad de este espacio no permite un análisis minucioso, referiré sucintamente algunas de sus más paradigmáticas expresiones.

El retablo mayor de la Iglesia del Colegio del Corpus Christi de Valencia constituye una de sus más tempranas y acabadas realizaciones. En 1601, el Patriarca Juan de Ribera recibió como presente un valioso crucifijo alemán, tenido y reputado por milagroso, que acogía en su peana un fragmento del Lignum Crucis. Con la intención de ofrecerlo a su culto, ordenó la reforma del retablo mayor, abriendo un ajustado camarín tras el lienzo del encasamento principal, a fin de albergar la preciada imagen y reliquia. Dispuso asimismo la fabricación de un mecanismo de tramoya, que había de permitir, mediante un sencillo juego de poleas y contrapesos, el abatimiento de la pintura; una suerte de primitivo telón de boca que con gran solemnidad descendía para descubrir la prodigiosa escultura (se constata el uso del telón de boca en el teatro español sólo desde finales de la década de 1620) ${ }^{37}$. En 1606, se reemplazó la anterior pintura por una monumental Última Cena de Ribalta. Pero el aparato no acaba aquí; abundando en la teatralidad, se dispuso un culto especial para su exhibición: todos los viernes del año y mientras la iglesia permanecía en penumbra, descendía el telón para exponer el crucifijo, que se descubría iluminado por hachones de cera y velado por cinco cortinas de diferentes colores; entonces los colegiales entonaban el Miserere y se descorrían ceremoniosamente los velos, permitiendo finalmente el acceso visual a la anhelada imagen milagrosa. Un espectáculo de gran efectismo, que sin duda movería al arrobamiento de los fieles (y que en gran medida recuerda a aquel referido con ocasión de la exposición ordinaria del Cristo de Burgos).

A la sazón, el empleo de luces tamizadas por filtros de color es práctica frecuente en el teatro; práctica tempranamente ensayada por Leonardo y codificada por Serlio y Leone de'Sommi. Desde mediados del siglo XVII, estas fórmulas y recetas luminotécnicas -como gran parte de los mecanismos y tramoyas que servirán a los escenarios europeos- se difunden velozmente a

puede encontrarse en: JUSTI, C., Velázquez y su siglo, Madrid, Espasa, 1999, p. 282; la de Baccio del Bianco en: BALDINUCCI, F., Notizie de' professori del disegno da Cimabue in qua... Florencia, 1728, p. 330

36 Ver Notas 4 y 5 . En adelante, mis palabras serán en gran medida deudoras de los artículos citados.

37 Empleado en 1627 por Cosimo Lotti para la representación de la égloga lopesca La selva sin amor. Así se deduce de la descripción del propio dramaturgo de la puesta en escena. Cit. REYES PEÑA, M., «Teatro barroco en España y Portugal», en DÍEZ BORQUE, J. M. (ed.), Teatro y Fiesta del Siglo de Oro en tierras europeas de los Austrias, Madrid, SEACEX, 2003, p. 71-72. Cfr. asimismo: RODRÍGUEZ G. DE CEBALLOS, A., "Escenografía y tramoya en el teatro español del siglo XVII", en EGIDO A. (ed.), La escenografía del teatro barroco, Salamanca, Universidades de Salamanca e Internacional Menéndez Pelayo, 1989, p. 42. 
través del conocido manual escenográfico de Nicola Sabbatini (Pratica di fabricar scene e machine ne'teatri, 1638) ${ }^{38}$.

En cuanto al sistema mecánico aquí descrito, muy extendido en Valencia y bautizado bocaporte ${ }^{39}$ (lienzos corredizos que sólo en ocasiones principales revelan los contenidos múltiples de las cajas practicadas en sus espacios posteriores), es compartido por otros conocidos retablos españoles, caso del realizado para la Sacristía de El Escorial por José del Olmo (con soberbio telón pintado por Claudio Coello, que oculta el camarín en que se deposita la Sagrada Forma incorrupta de Gorkum) o de la espectacular máquina churrigueresca instalada en San Esteban de Salamanca (el telón, una Asunción de Antonio Palomino, queda circunscrito al arco frontal del ostensorio).

El retablo mayor de la Iglesia de los Santos Justo y Pastor de Granada (antiguo Colegio Jesuita de San Pablo) abre la segunda gran serie de estos aparatos escénicos. Obrado por Díaz del Ribero (1654-1660), introduce variados artificios de indudable raigambre teatral. El imponente tabernáculo central, que de ordinario muestra las tallas de la Virgen y los Evangelistas de Pedro de Mena, gira sobre sí durante la solemne exhibición del Sacramento, descubriendo en el envés una rica custodia. Los lienzos de las calles laterales, obra de Atanasio Bocanegra, se deslizan sobre correderas, revelando relicarios y bustos de santos. Finalmente, el cuerpo central del ático, ocupado por otro lienzo del pintor granadino, gira sobre su eje, mostrando tras de sí un Crucificado de talla y dos relicarios. No resulta difícil vincular estos artificios con otros ya presentes en los teatros y corrales del siglo XVII: bofetones (mecanismo giratorio que permite la aparición y desaparición súbita de personajes y objetos), devanaderas (que permiten la rotación de bastidores pintados por sendas caras), periactos (prismas triangulares giratorios a cuyas facetas se adhieren los lienzos que precisa la escena; máquinas que algunos traductores de Vitrubio, como Cesariano o Caporali, no dudan en comparar con los facistoles para cantorales $)^{40}$ y mutaciones de bastidores.

Tampoco es difícil encontrar artefactos similares en otros conjuntos españoles, caso del tabernáculo adscrito al retablo de la Capilla del Sagrario de la Catedral de Segovia (un globo de ángeles, con cuatro frentes definibles, que gira sobre una plataforma circular; la faceta frontal contiene un manifestador para celebraciones ordinarias, dotado de puertas deslizables para la exposición del Sacramento. En su concepción teatral vienen a colaborar la infinidad de ángeles ingrávidos o asentados sobre nubes, que evocan los frecuentes vuelos escénicos de comedias y autos; el rico

38 Dentro del interés por los juegos cromáticos vinculados con la manipulación luminotécnica, cabe referirse a la lámpara ideada por Leonardo -y presumiblemente destinada a los espectáculos milaneses-, recogida en los Códices Atlántico (Ambrosiana de Milán) y F (Instituto de Francia). Cit. ARREGUI, J. P., «Luminotecnia teatral en la primera mitad del siglo XIX: de la herencia barroca a la introducción del gas», Stichomythia, 3 (2005), pp. 3-4 (Recurso electrónico). Ver también: RODRÍGUEZ G. DE CEBALLOS, A. (1989), Op. cit., p. 41; y RODRÍGUEZ G. DE CEBALLOS, A. (1992), Op. cit., p. 140.

39 Sirvan de ejemplo los varios retablos que emplean este mismo sistema en el propio Colegio del Corpus Christi, o en las también valencianas Iglesia de San Pablo y Basílica de los Desamparados.

40 GONZÁLEZ ROMÁN, C., Spectacula, Teoría, Arte y Escena en la Europa del Renacimiento, Málaga, Universidad de Málaga, 2001; especialmente, Capítulo III, pp. 85-121. 
pabellón de fingido brocado que, a modo de telón con guardamalletas, recogen varios querubes para iniciar la función allí representada; o la figura de San Fernando, que irrumpe por entre los pliegues de un segundo pabellón festoneado, adoptando su ya habitual actitud declamatoria); o del expositor aovado del retablo de las Clarisas de Murcia (con puertas deslizables accionadas por un sencillo mecanismo de cuerdas y poleas oculto en su espacio posterior).

Incluso llega a constatarse el uso de escotillones y deslizadores horizontales; es el caso del manifestador del retablo mayor de la Parroquia de Villanueva de la Jara

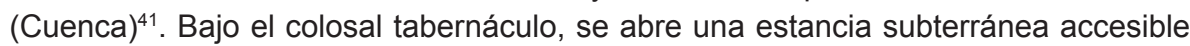
a través de una portezuela disimulada en el lateral derecho del retablo; cuarto en que se alojaban el manifestador y los artefactos empleados para su ascenso y descenso, así como los operarios encargados de su manipulación. Huelga reseñar las concomitancias con los fosos para maquinaria escénica de los teatros auriseculares. El mecanismo empleado era sencillo: un sistema de poleas, maromas y contrapesos que engarzados a una rueda vertical y movidos por un torno (una suerte de primitivo montacargas), desplazaban verticalmente el manifestador. La tramoya se completaba con un segundo dispositivo, que permitía el movimiento horizontal de la pieza: una tabla se deslizaba desde la parte posterior del retablo y penetraba en el expositor a través de una ranura abierta en su base; ajustadas tabla y custodia, el conjunto se desplazaba hacia delante, haciendo llegar la sagrada pieza a manos del oficiante.

Y si la nómina de aparatos permanentes con cualidades escenográficas es grande, mayor debió ser el número que con motivo de las prodigadas festividades del período se erigió en estos espacios. Sirva de muestra el altar diseñado por el ingeniero-escenógrafo José Caudi ${ }^{42}$ para la Iglesia del Convento-Hospital Antón Martín de Madrid, con ocasión de las Fiestas de Canonización de San Juan de Dios en 1691. El contrato firmado por el valenciano ${ }^{43}$ es prolijo en detalles sobre la traza y aderezo del altar, coherentes en lo arquitectónico con la más moderna práctica artística. Respecto de la tramoya ideada, la descripción es confusa, aunque sin dificultad se perciben la riqueza y vivacidad de sus efectos. Sobre las gradas del altar se disponían las figuras de San Juan de Dios y el Niño, flanqueando una granada y una estrella. Al tiempo de manifestarse el Sacramento, y siguiendo el compás de la música, la granada se desgajaba y la estrella se desvanecía, emergiendo por entre un rutilante rompiente de gloria las figuras de Dios Padre y la Virgen, que ahora portaba en sus brazos

41 Obrado por el escultor y ensamblador Francisco Montllor y fechado entre 1693 y 1697. A este artífice también compete la ejecución de otro espectacular retablo-tramoya, el de las Justinianas de Albacete. Para éstas y otras posteriores referencias: LUJÁN LÓPEZ, F. B., «El Tabernáculo y el Expositor Eucarístico del Retablo del Altar Mayor de la Iglesia Parroquial de Villanueva de la Jara (Cuenca). Estudio y análisis del estado de conservación de una obra singular», en Actas del XV Congreso de Conservación y Restauración de Bienes Culturales, Murcia, Ligia Comunicación y Tecnología, 2004, pp. 735-752.

42 Autor de las tramoyas de la comedia Hado y Divisa de Leonido y Marfisa de Calderón, representada en Madrid en 1680, con ocasión de las bodas de Carlos II y María Luisa de Borbón. Ver: PÉREZ SÁNCHEZ, A. "José Caudí, arquitecto y decorador», en GARCÍA LORENZO, L. (ed.), Actas del Congreso Internacional sobre Calderón y el Teatro Español del Siglo de Oro, Madrid, CSIC, 1983, pp. 1651-1671.

43 Publicado por A. Pérez Sánchez, Ibídem, pp. 1663-1668. 
al Niño; completaba el conjunto un cerco de ángeles. Seguidamente, con movimientos bien coreografiados, ascendía San Juan y descendían Virgen y Niño, disponiéndose las figuras a igual altura. El Niño abandonaba los brazos de la Madre y se instalaba en los del Patriarca, descubriendo en su pecho el Sacramento. Entretanto, de las nubes que cubrían la parte baja del altar, surgía una multitud de ángeles portando velas encendidas, quedando todo lleno de luces y resplandores. Así permanecía el aparato hasta que llegado el momento se invertían los movimientos descritos y se clausuraba la función.

Como ya se indicó, especial connotación escenográfica debió revestir el Jubileo de las Cuarenta Horas. Apenas conocida en nuestro país, cualquier acercamiento a esta devoción exige una pequeña introducción ${ }^{44}$. Derivada de las funciones medievales del Triduo Pascual, la festividad moderna vio la luz en Milán, en 1527, en torno a la Iglesia del Santo Sepulcro, revistiendo carácter de plegaria expiatoria (alivio a los sufrimientos padecidos por la ciudad, a la sazón devastada por las Guerras de Italia) y sin calendario fijo (celebrándose en Semana Santa y otras efemérides del año litúrgico). Durante cuarenta horas, el Sacramento quedaba expuesto a la adoración de los fieles. Pronto prendió esta costumbre, que se extendió por todas las iglesias de la ciudad, adquiriendo carácter perpetuo (un templo sucedía a otro en la celebración). Y su popularidad siguió creciendo, alcanzando Francia antes de finalizar el siglo. Pero la solemnidad, carente de uniformidad y proclive a ciertos excesos, vio rápidamente degenerar. Primero, Carlos Borromeo (1577) y, más tarde, Clemente VIII (1592) intentaron poner fin a los abusos detectados, regulando largamente las celebraciones. Las instrucciones del Pontífice, modeladas sobre las disposiciones del Arzobispo de Milán, contienen consideraciones que resultan de nuestro particular interés: el altar debía adornarse con la mayor solemnidad y decoro, evitando los excesos suntuarios, y poseer un tabernáculo para recibir la Eucaristía, que debía quedar oculto tras un velo de seda; la iglesia debía permanecer en penumbra, a fin de destacar la presencia del Santísimo; las campanas debían llamar a la celebración dos horas antes del comienzo de la función; debían cantarse letanías, versos y oraciones; predicarse un sermón breve; etc.

Pese al estricto comedimiento exigido para la decoración del altar, este precepto apenas llegó a observarse, descollando pronto el espectacular aparato empleado por los Jesuitas durante sus celebraciones, oficiadas -ya desde mediados de siglo- durante los tres días de Carnestolendas. Con la intención declarada de desviar al pueblo de la vanidad carnavalesca y a fin de atraerse a un gran número de fieles, los Jesuitas no dudaron en servirse de su siempre fastuosa maquinaria lúdico-propagandística. Ya a principios del siglo XVII, el adorno que durante este particular jubileo exhibía la romana iglesia de // Gesù, superaba en suntuosidad a cualquier manifestación festiva

44 Las referencias a la historia de esta festividad pueden encontrarse en: MARTÍN MÁRQUEZ, A., Op. cit: y WEIL, M. S., "The Devotion of Forty Hours and Roman Baroque Illusions», Journal of the Warburg and Courtauld Institutes, 37 (1974), pp. 218-248, que incluye un completísimo estudio de los montajes romanos; en este sentido, ver también: NOEHLES, K., "Teatri per le Quarant'ore e altari barocchi», en FAGIOLO, M. y MADONNA, M. L. (eds.), Barocco Romano e Barocco Italiano, Roma, Gangemi, 1985, pp. 88-99. 
(incluidas las habidas en las Basílicas de San Pedro o San Juan de Letrán); y el lujo siguió aumentando. Una vez quedó instituido, el Teatro de las Cuarenta Horas de II Gesù se erigió una de las principales festividades del calendario litúrgico romano. Y a juzgar por los Avvisi, sus aparatos debieron causar la más grande expectación. En su celebración confluían la más ostentosa decoración (tapices, damascos y otras ricas colgaduras cubrían por entero sus muros; reliquias, arquetas, vasos de plata y otras alhajas adornaban el altar; infinidad de hachas y candelas iluminaban el tabernáculo) y los más solemnes actos (procesión del Sacramento, sermones, himnos, letanías y plegarias). La masiva asistencia de fieles, la concurrencia de otras religiones y cofradías y el concurso de las más altas autoridades eclesiásticas vinieron a reforzar su notoriedad y espectacular desarrollo (si bien la Compañía no fue la única que dispuso y acogió esta devoción; especial boato revistieron las celebraciones patrocinadas por Francesco Barberini en la Iglesia de San Lorenzo in Damaso).

Fueron precisamente los Jesuitas los responsables de la introducción y consolidación de estas formas festivas en España e Iberoamérica. Su penetración en nuestro país puede fecharse con toda seguridad a comienzos de la centuria ${ }^{45}$. Así lo confirman dos de las Historias manuscritas de la Compañía en Andalucía, las de Jaén ${ }^{46}$ y Sevilla ${ }^{47}$, ambas datadas de la segunda década del XVII. Especialmente elocuente resulta la descripción de la celebración en la ciudad jiennense, habida en su Catedral, y que no sólo contaría con el decidido apoyo de su Obispo, don Sancho Dávila, sino que parecería reproducir las esplendentes maneras vistas entonces en Roma ${ }^{48}$.

45 Adelantando la datación tradicionalmente consignada por la crítica en más de 30 años; las fechas hasta ahora sugeridas rondaban la medianía de la década de 1640. Cfr. MARTÍN MÁRQUEZ, A., Op. cit.

46 En el marco de las misiones que los padres jesuitas desarrollaron en la ciudad desde 1611: Historia de la entrada y misión de la Compañía de Jesús en la ciudad de Jaén. Jaén, 4 de Abril de 1617. Testigo de vista de lo aquí referido P. Juan Méndez, manuscrito conservado en el Archivo Histórico Diocesano de Jaén e íntegramente transcrito por LÓPEZ ARANDÍA, M. A.: El colegio de San Eufrasio de la Compañía de Jesús de la ciudad de Jaén (1611-1767), Jaén, Ayuntamiento de Jaén, 2005, pp. 327-438.

47 Historia de la casa profesa de la Compañía de Jesús de Sevilla desde el principio del año 1611 hasta fin del año de 1614, manuscrito conservado en la Biblioteca del Hospital Real de Granada (con la signatura A-040-12), e íntegramente transcrito por HERRERA PUGA, P.: Los jesuitas en Sevilla en tiempo de Felipe III, Granada, Universidad de Granada, 1971, pp. 49-83. Así reza la noticia de una misión llevada a cabo en Utrera en 1612: «Vase todos los años a esta misión [...] a petición de una congregación que en aquel lugar hay, que hace la fiesta de las Cuarenta Horas en las Carnestolendas y para que en ella se proceda con el modo que se debe, va la Compañía a predicar, y con esta ocasión se hacen todos los años doctrinas generales y muchas personas confiesan y comulgan en aquellos tres días [...] solo el lunes de carnestolendas se habían gastado quinientas formas...»; pp. 61-62.

48 Tras referirse a algunas fiestas auspiciadas por la misión jesuítica, el texto alude a «la que la Compañía suele hacer [en] los tres días de Carnestolendas, luego desde el primer año se introdujo [la misión arribó a Jaén en 1611] [...] escogiendo [...] la Catedral, donde en el trascoro, con las colgaduras y riquezas que el señor Obispo daba, se levantaba un altar lleno de mil relicarios, ramilleteros, candeleros de plata y otras curiosidades que el señor don Sancho tenía en su capilla, descubriendo el Santísimo Sacramento en unas andas muy curiosas [...] acompañado de mucha cera [...] y lo restante de la iglesia, [se] adornada con las tapicerías de su casa. Por las mañanas comulgaban las congregaciones, a las tardes había sus sermones [...] con increíble concurso de auditorio, asistiendo siempre la música de la Iglesia Mayor, y aun el cabildo eclesiástico dejaba aquellos días su coro [...] Con esto se sintió notable mudanza en la ciudad, porque tales días había mil locuras y desórdenes y pendencias y de ordinario algunas muertes [...] Y ha querido Dios que con estas fiestas [...] ha cesado aquel alboroto y más parece Semana Santa que tiempo de Carnestolendas». LÓPEZ ARANDIA, M. A. Op. cit., p. 338. El texto ha sido adaptado a la actual ortografía a fin de facilitar su lectura. 
A mediados de la década de 1640, esta práctica encontró poderoso refrendo en las disposiciones del Rey, que preceptuó su culto en Madrid con carácter rotativo, de modo que «por seis meses esté el Santísimo Sacramento descubierto quarenta horas en cada iglesia [...] como se hace en Roma» ${ }^{49}$. Los luctuosos acontecimientos de la Corte -recuérdese el general carácter expiatorio que reviste la celebración- y el favorecimiento regio del culto eucarístico, vinieron a converger en su singular impulso oficial ${ }^{50}$.

Desgraciadamente, no es mucha la documentación conservada (no obstante, viene a corroborar la extensión de esta práctica); escasa o nula, la gráfica; y pocos los estudios dedicados a esta devoción ${ }^{51}$.

Substancialmente distinta se presenta la situación en Italia, donde se conservan numerosas relaciones y diseños de estos aparatos. Su concepción, al menos desde $1628^{52}$, fue decididamente escenográfica, sirviéndose a este fin de la perspectiva ilusionista, empleando bastidores laterales y telones pintados, amén de sugestivos efectos lumínicos. El aparato se disponía sobre el ábside de la iglesia (operando el arco absidal como eficaz embocadura), oculto tras una cortina de tafetán. Efectuado el traslado de la Eucaristía, las ventanas se cubrían, quedando la iglesia en penumbra, y el telón comenzaba a elevarse. Surgía entonces el fastuoso escenario de gloria del Sacramento, envuelto entre los fulgores de cientos de lámparas ocultas tras el colosal aparato, obrado con los más avanzados recursos del ilusionismo pictórico.

Las analogías con la mise-en-scène del teatro cortesano no pueden ser más evidentes: sirvan de testimonio, entre otros, los diseños de Pietro da Cortona (1633; San Lorenzo in Damaso), Carlo Rainaldi (1650; II Gesù) o Andrea Pozzo (1685; II Gesù). Solamente los versos que principian El gran teatro del mundo de Calderón parecen apropiados a la descripción de semejante escenario:

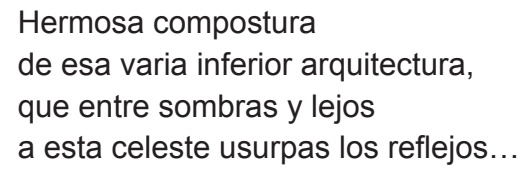

49 Así lo recoge José Pellicer en sus Avisos (14 de julio de 1643) y lo confirma una relación conservada en la Academia de Historia [con la signatura 9/3674 (47)], citada por Martín Márquez: Op. cit., pp. 10-11.

50 Incluso en su testamento, Felipe IV manda y encarga «a todos los Sucessores de esta Corona [...] se continúe la solemnidad de las Quarenta Horas, que en cada principio de mes tengo fundada [en la Capilla del Alcázar], haciéndose con toda aquella devoción, y authoridad que más se pudiere executar»; ABREU Y BERTODANO, J. A., Colección de tratados de paz, alianza, neutralidad, garantía, protección... hechos... hasta el feliz reynado del rey N.S. D. Fernando VI. En la qual se comprehenden otros mucho actos públicos, y reales..., T. 7, Madrid, 1751.

51 En un próximo artículo, espero arrojar luz sobre esta desconocida práctica en nuestro país.

52 Fecha en la que Bernini lleva a cabo el montaje de las Cuarenta Horas de la Capilla Paulina del Palacio Vaticano. Hasta entonces, la disposición de altares, capillas e iglesias concuerda con la conocida para otras celebraciones espectaculares, fundamentada antes en el enriquecimiento y transmutación decorativa del espacio (pese a lo que tiene de teatral esta alternativa) que en el uso decidido de elementos extraídos de la escenografía. WEIL, M. S., Op. cit. 
Aunque me inclino a pensar que los montajes españoles difícilmente alcanzaron el fasto y la grandeza de los romanos, no puede dudarse de la irradiación de los modelos italianos a nuestro país; una proyección cifrada no sólo en las fluidas relaciones políticas y artísticas con la Península itálica, sino en los documentos y testimonios conservados, y en la deuda que esta festividad mantiene con el aparato y liturgia de las celebraciones del Triduo Pascual (especialmente, con los monumentos de Semana Santa, que no dudaron en introducir semejantes elementos escenográficos).

En cualquier caso, la información que ha llegado a nosotros es fragmentaria y de origen diverso, debiendo sumergirnos en las oscuras aguas de la especulación; no obstante, permite fehacientemente imaginar una celebración regalada de gran espectacularidad. Siguiendo a Carl Justi, fue el ingeniero-escenógrafo florentín Cosimo Lotti, arribado a Madrid en 1626, el responsable de la renovación del aparato escénico de las Cuarenta Horas ${ }^{53}$; información que permite suponer la decidida adopción de los más modernos usos escenográficos (al menos, en las iglesias y capillas de la capital); una efectiva italianización que vendría a respaldar la también conocida participación de su sustituto en Madrid, Baccio del Bianco, en la elaboración de estos montajes ${ }^{54}$.

En Granada, las celebraciones habidas en la Iglesia del Colegio de San Pablo, debieron gozar de especial predicamento, a juzgar por el empleo temprano de carteles impresos para anunciar el programa y predicadores de las distintas jornadas. Tres han llegado a nuestros días: 1674,1675 y $1752^{55}$. No cuesta imaginar las elevadas dosis de teatralidad que debieron alcanzar estas jornadas, asistidas en su escenificación por el espectacular retablo-tramoya de Díaz de Ribero.

El investigador Martín Márquez, en el único estudio monográfico consagrado a esta devoción en España, ha llegado a reconstruir el cuerpo de la festividad en la ciudad de Zamora. A nuestros fines, sus revelaciones resultan de capital interés, por cuanto reproduce una celebración de gran aparato, servida de abundante utillaje escenotécnico. La fiesta, instituida en aquella ciudad en la medianía del siglo XVII, cuenta con una comisión encargada de su organización, que en número de cuatro conforman los representantes de los Cabildos civil y eclesiástico, la Parroquial de San Juan (lugar de celebración) y el pueblo. A estos sectores corresponde sufragar, en cantidades iguales, buena parte de los elevadísimos costes de los festejos ${ }^{56}$, viniendo

53 «Lotti dio también a la Corte nuevas ideas para el monumento del Jueves Santo y para la exposición de las Cuarenta Horas», aseveración que el historiador alemán fundamenta en las numerosas descripciones que de sus obras contienen los informes de los embajadores florentinos entre los años 1628 y 1637 ; JUSTI, C., Op. cit., p. 282, Nota 15

54 Ver Nota 34

55 Conservados en la Biblioteca del Hospital Real de Granada, con las signaturas: A-031-132-(22); A-031132-(28); y A-031-132-(67).

56 Para 1749, cada uno de los mayordomos debía aportar 1617 reales y 6 maravedíes; para 1752, 2036 reales y 4 maravedíes. Cabe considerar estas cifras astronómicas, considerando, como hace el autor, que en 1771, un labrador ingresaba anualmente en torno a 720 reales; un panadero, 420; o un frutero, 310: MARTíN MÁRQUEZ, A., Op. cit., p. 19. 
a completar el presupuesto las cuantiosas limosnas ofrecidas por el Municipio (extraídas de la cuenta de propios) y los fieles ${ }^{57}$. Pero la aportación de las entidades mayores no acaba aquí: Ciudad y Catedral ceden su propio mobiliario y ornamento; el primero contribuye asimismo con luminarias; y el segundo, con órgano y capilla (que no cabe pues deducir de los costes). Una parte del exorbitante presupuesto se destina a costear algunos actos paralelos, caso de las corridas de toros (que a su vez generan ingresos) o de los fuegos de artificio (uno de los gastos más elevados de la fiesta). Pero como resulta previsible, el mayor desembolso recae sobre el aparato escénico de la celebración, anualmente renovado, y que acomoda mutaciones y otros efectos de tramoya ${ }^{58}$. A la función acuden los fieles en masa, la iglesia se engalana con hermosas alhajas, sus paramentos se recubren con tafetanes, el órgano resuena con solemnidad. Y entonces se descubre el altar ${ }^{59}$ :

«Las tramoyas fueron 4. La primera era un espejo de lazos, grandioso dibujo, claraboya en forma de rastrillo, que apartándose por de dentro una cortina, se veían las luces por más de mil cortaduras, y bajándose el rastrillo para abajo se veía el camarín donde estaba el Santísimo. Se subía el Espíritu Santo, el cual se subía para arriba, en forma de nube, y otra nube se bajaba para abajo, en que descubría el Santísimo; y encima a Dios Padre con [un] jeroglífico que decía: Filius meus diletus ...».

Las referencias conservadas, manifiestamente confusas, abundan en la descripción de los efectos de tramoya, soslayando la estructura del monumento. No obstante, permiten constatar la espectacularidad del aparato prevenido, que se cimienta en la adopción de una maquinaria escénica análoga a la utilizada en los teatros cortesanos y los carros para autos.

Otra práctica festiva poco conocida, que cabe situar en un estadio intermedio entre las Cuarenta Horas y los Monumentos de Semana Santa (objeto final del presente análisis), y que explota asimismo dispositivos de inspiración teatral, es la también importada Devoción del Santo Sepulcro, si bien su alcance parece más limitado y no cabe invocar una generalización. No sin razón, Rodríguez G. de Ceballos ha puesto en relación con esta piadosa práctica un diseño conservado en los Uffizi y atribuido al pintor y también escenográfo Francisco Rizzíio: un

57 Para dos de las fechas reseñadas en la nota anterior, 1749 y 1752, las limosnas ascendieron respectivamente a 1047 y 1560 reales. Ibídem, p. 26.

58 Ibid., p. 36.

59 Ibíd., p. 40. Cita extraída (y transcrita con erratas; corregidas en el presente) de: LORENZO PINAR, F. J. y VASALLO TARANZO, L., Diario de Antonio Moreno de la Torre (1673-1679), Zamora, Instituto de Estudios Zamoranos Florián de Ocampo, 2001, p. 88.

60 RODRÍGUEZ G. DE CEBALLOS, A. (1992), Op. cit., pp. 141-143. Recoge asimismo indicaciones sobre esta práctica. Por otro lado, este dibujo ha sido igualmente puesto en relación con el fastuoso Monumento de Semana Santa que debía adornar la Catedral de Toledo, obra documentada de Rizzi. En su ejecución, contó con la colaboración -entre otros- del también escenógrafo Dionisio Mantuano: un espectacular dispositivo escenográfico de «muy considerable Costa por las muchas Pinturas de Maravillosa perspectiva de que se com- 
deslumbrante decorado levantado sobre potente basamento y centrado por un baldaquino de estilizadas columnas torsas, que acordona una vigorosa galería de planta semicircular; en la base del baldaquino, dos ángeles gravitantes sostienen un lienzo con el cuerpo exangüe de Cristo. Salpican el conjunto prefiguraciones eucarísticas y variadas escenas y símbolos de la Pasión y Muerte de Jesucristo.

Quizá con esta ceremonia puede asimismo vincularse el celebrado telón -nótese la nominación utilizada- que el ilustrado Ceán atribuye a un casi desconocido Morey ${ }^{61}$ :

«que pintó para la parroquia de santa Eulalia [de Palma de Mallorca] de cincuenta y cuatro palmos de ancho y algo más de largo, que sirve en la semana santa y llaman Velum templi: representa el sepulcro de Cristo con mucho acompañamiento de ángeles, con insignias de la pasión y el Agnus Dei».

En cualquier caso, se conoce asimismo del empleo de estos velos -que se acompañan de algunos efectismos de índole teatral- en otras ceremonias habidas durante la Semana Santa; así narraba Blanco White la celebración del Miércoles Santo en la Catedral de Sevilla62:

«La misa de este día comienza dentro de un velo blanco que oculta al sacerdote y demás ministros oficiantes, y así prosigue hasta que se cantan las palabras "el velo del templo se partió en dos". En este momento el velo desaparece como por arte de magia, y los asistentes pueden oír el estruendo de unos cohetes ocultos que pretenden imitar el ruido de un terremoto».

Por razón misma de su carácter sobrenatural, la representación de la ruptura del velo (Mateo 27:51, que antecede a un formidable terremoto; y Lucas 23:45, que sigue a un eclipse de sol), se descubre campo especialmente abonado para la aplicación de recursos escenotécnicos. Es el caso de las funciones de Resurrección ejecutadas ante el Monumento Pascual de la Seo de Zaragoza, recogidas en un resumen manuscrito de su consueta, fechado en $1606^{63}$ :

«Luego se siguio un estruendo y despues del se ronpio un belo blanco y aparecio un altar muy adornado con muchas flores y enrramado alrededor en el cual avia çinco imagines muy lindas de bulto doradas [...] Luego vaxo

pone, como por la gran Maquina de madera y otros materiales que se gastaron». Cit. en: NICOLAU CASTRO J., «Precisiones documentales sobre el monumento barroco de la Catedral de Toledo y un dibujo madrileño del último tercio del siglo XVII», Archivo Español de Arte, 246 (1989), p. 217.

61 CEÁN BERMÚDEZ, J. A., Op. cit., T. 3, p. 198. Voz: MOREY.

62 BLANCO WHITE, J. M., Cartas de España, Madrid, Alianza, 1983, pp. 217-218.

63 CALVO RUATA, J. I. y LOZANO LÓPEZ, J. C., «Los Monumentos de Semana Santa en Aragón (Siglos XVII-XVIII)», Artigrama, 19 (2004), pp. 105-106. Ambos refieren asimismo la ceremonia de reserva del Santísimo en la Catedral de Huesca, habida tras la celebración de la missa in coena domini de Jueves Santo, en la que un ángel puesto en tramoya desciende de las alturas para romper la cortina de tafetán carmesí que cubre el Monumento Pascual; pp. 99-100. 
un angel con una espada en la mano y rompio un belo de tafetan carmesi y apareçio una figura de bulto de un Christo resucitado...».

Llegados a este punto, cabe por fin abordar el examen de los Monumentos de Jueves Santo, último hito de este recorrido teatral. ¿Pero qué se entiende por Monumento de Semana Santa, de Jueves Santo, Pascual o simplemente, Monumento o Perspectiva, como comúnmente aparecen citados en las fuentes? El Tesoro de Covarrubias (1611) ofrece una definición compendiosa del término monumento: «vulgarmente se toma por el túmulo y aparato que se haze en toda la Yglesia Católica el Jueves y Viernes Santo, donde puesta un arca en forma de sepulcro en que estuvo aquellos tres días el cuerpo de Nuestro Redentor Jesu Christo». Covarrubias distingue pues dos elementos: un arca o sagrario destinado a acoger la reserva eucarística durante la noche del Jueves Santo, y un aparato que hace las veces de decorado englobante. Del colosal desarrollo de estos dispositivos habla la propia acepción moderna del término.

No sin razón refiere Covarrubias el carácter tumular de estas estructuras. En realidad, el lexicógrafo no hace sino recoger una definición en todo coherente con la práctica artística de su tiempo: formal, por cuanto los primeros Monumentos siguen en gran medida las trazas de los catafalcos efímeros de la familia real (los Monumentos de Sevilla, Córdoba y El Escorial pueden dar fe de esta afirmación); e iconográficamente, en tanto que estas colosales máquinas vienen a vincularse con la Pasión y Muerte de Jesucristo y a entroncar con ciertas tentativas de reconstrucción de las más distinguidas arquitecturas hierosolimitanas (Templo de Salomón y Santo Sepulcro, que aparecen aquí, como en tantos otros casos, pervertidas o contaminadas) ${ }^{64}$. Habrá que esperar a la llegada a Madrid de los ingenieros-escenógrafos florentinos -y la consecuente difusión de sus modernos usos- para que el aparato de estas y otras festividades litúrgicas adopte un carácter marcadamente escenográfico. Y así ocurrirá por vez primera en nuestro país en la Semana Santa de 1628: nuevamente Lotti será el precursor de la reconversión teatral de estos dispositivos, y la madrileña Iglesia del Hospital de los Italianos, su más pertinente coliseo ${ }^{65}$.

«Il Re et [la] Regina [...] furono hiersera all'Ospedale degli Italiani a sentir cantar un Miserere et vedere l'apparato che si è fatto per il monumento della Settimana Santa. Cosimo Lotti ha fatto l'invenzione che è riuscita cosa bella et è piaciuta

64 Tampoco resulta gratuito el empleo del término arca. El uso de la planta centralizada o la presencia combinada del velum templi hace de estos aparatos evocaciones a escala del Sanctasanctorum del Templo. Respecto de las perversiones y contaminaciones que experimentan las tentativas de reconstrucción del Templo de Jerusalén: Cfr. RAMíREZ, J. A., Construcciones ilusorias. Arquitecturas descritas, arquitecturas pintadas, Madrid, Alianza, 1983, Capítulo 5. Ciertamente rica en interpretaciones parece presentarse esta triple relación monumento-catafalco real-arquitectura hierosolimitana. No obstante, la cortedad de estas páginas impide un deseable acercamiento.

65 Archivio di Stato di Firenze, Mediceo del Principato, filza 4956, fol. 81. Carta de Averardo de’ Medici di Castellana, embajador de la Toscana en Madrid, a Dimurgo Lambarri, Secretario del Gran Duque; 15 de abril de 1628. Cit. en: CHAVES MONTOYA, M. T., El espectáculo teatral en la corte de Felipe IV, Madrid, Ayuntamiento, 2004, p. 47. 
molto alle Maestà loro et a tutta la Corte. Vi erano diverse apparenze del Limbo, Purgatorio et Inferno et due nuvole d'Angeli che scendevano cantando, ordinato tutto con buona et dilettevole prospettiva».

Aunque lacónica, la explícita referencia a la ordenación perspectívica del decorado ${ }^{66}$ parece sugerir el empleo de bastidores en fuga y telón/telones de fondo; y con esta disposición, es probable que las representaciones del Limbo, el Purgatorio y el Infierno sean el resultado bien de las sucesivas mutaciones del escenario, bien de la subdivisión en planos o registros de un decorado único ${ }^{67}$. La presencia de dos aracelis completa este renovado cuadro escénico.

Sea como fuere, a partir de este hito inaugural, aparatos con similares características emergerán por toda la geografía española (no obstante la pervivencia del primero de los tipos); monumentos agrupados bajo el denominador común de la perspectiva, servidos de los avanzados recursos de la construcción ilusionista: ya mediante bastidores en fuga y telones pictóricos, ya por concreción plástica, por materialización tridimensional de efectos perspectívicos (o por el uso combinado de sendas soluciones). Esto es, los Monumentos se valdrán de las soluciones escenográficas aportadas por los diferentes lenguajes artísticos (se alude pues a una arquitectura, una escultura y una pintura empleadas con una finalidad ilusionista). Circunstancia que no debe extrañar, habida cuenta de que las escenas urbanas tipificadas por Serlio aúnan bajorrelieves y bastidores pictóricos; e igual puede decirse de las escenografías definidas por el ensamblador Antonio de Torreblanca, primer tratadista español en abordar la construcción perspectívica de la escena teatral (Los dos libros de geometría y perspectiva; 1616-1617), que combinan la planitud de un telón de fondo pictórico con el relieve de los encuadramientos laterales. Y por cuanto esta fórmula mixta es práctica asimismo común en la fabricación de decorados teatrales: buen ejemplo lo constituye el enmarque arquitectónico utilizado por Pietro da Cortona para el montaje de las ya referidas Cuarenta Horas de San Lorenzo in Damaso (1630); o los bajorrelieves laterales empleados en la mítica representación de La Calandria de Bibbiena en Urbino (1513). Y es, en este sentido, que parece referirse El Greco, cuando categórico establece: «y bien se entiende que en la escena no se pinta sino que se fabrica en perspectiva» ${ }^{68}$.

66 En este sentido, conviene recordar que perspectiva y escenografía -esa skenographia de la que abominaba Platón- fueron, desde antiguo, términos sinónimos; el Humanismo recuperó esta acepción, que se extendió sin apenas alteraciones durante el Barroco. Cfr. GONZÁLEZ ROMÁN, C., «Lo fingido [parece] verdadero: significado y uso del término perspectiva en los discursos sobre escenografía de los Siglos de Oro», en DE LA PEÑA, C. et alii (eds.), Congreso Internacional Imagen y Apariencia, Murcia Universidad de Murcia, 2008, $15 \mathrm{pp}$.

67 Incluso cabe un error en la interpretación de la escena -error, por otro lado, común-, siendo meramente representado, en coherencia iconográfica, el Descenso de Cristo al Infierno de los Justos, episodio subsiguiente al Enterramiento y anterior a la Resurrección. Cfr. REAU, L., Iconografía del arte cristiano. Iconografía de la Biblia - Nuevo Testamento, T. I, Vol. II, Barcelona, Ediciones del Serbal, 1996, pp. 553 y ss.

68 GONZÁLEZ ROMÁN, C. (2008), Op. cit., pp. 3-5. Para éstas y otras cuestiones similares remito asimismo a su completísimo y ya citado estudio Spectacula... 
Recursos y efectos a los que tampoco es ajena -retomando el objetivo principal de este trabajo- la obra permanente de muchas capillas e iglesias, que apelan al ilusionismo perspectívico, a los procedimientos formales de la escenografía (y bajo la confusión o combinación de las diversas artes), para proceder a la transmutación decorativa de sus ambientes, generando con deslumbrante artificio espacios de cautivadora majestuosidad, de vertiginosa espacialidad, de turbadora apariencia.

Y así lo entiende la autorizada pluma del pintor, escenógrafo y tratadista Antonio Acisclo Palomino, que considera simultáneamente la delineación de teatros, altares y monumentos de perspectiva; la diferencia únicamente estriba en la inmutabilidad de las escenografías religiosas, "pues en los altares, y monumentos de perspectiva, como no tienen mutación, desde luego se ajustan las piezas de un término, quedando unidas unas con otras ${ }^{69}$.

Únicamente queda pues referir algunos elocuentes ejemplos. Afortunadamente, han llegado hasta nosotros gran número de diseños e incluso sobrevivido algunos viejos montajes; la tardía desaparición de esta festividad -mediados del siglo XX-ha favorecido la preservación de algunas de estas obras. De entre los que hacen uso de bastidores pictóricos (a la manera de las escenografías cortesanas) cabe citar los Monumentos aragoneses de Ibdes, Ateca, Samper de Calanda y Carenas, estudiados en profundidad por Calvo y Lozano ${ }^{70}$; el de Garinoaín (Navarra) $)^{71}$, o el singular y sin duda retardatario Monumento de la Parroquial de Villahermosa (Ciudad Real ${ }^{72}$.

Un ejemplo -en este caso magnífico- de aplicación combinada de recursos pictóricos y arquitectónicos ilusionistas lo constituye el Monumento de La Seo de Zaragoza $(1711-1712)^{73}$. Queda inserto en el trasaltar de la Capilla de San Marcos, enteramente oculto tras el gran lienzo del retablo central, que a modo de telón se repliega con motivo de las celebraciones de Pascua. Deja así a la vista un auténtico escenario de madera, embocado por el arco principal de la capilla y construido en perspectiva decreciente. El antiguo espacio de la capilla queda ahora levantado sobre una estructura en desnivel (como preceptúa Serlio para los escenarios teatrales, a fin de corregir algunos defectos

69 Una inmutabilidad quizá no verificada para el hito inaugural de Lotti, aunque sí en la práctica común de estos singulares dispositivos escenográficos. PALOMINO, A. A., Museo Pictórico y Escala Óptica, T. II, Madrid, 1724; la referencia puede encontrase en: Libro VIII, Capítulo VI, pp. 128-131.

70 Y que han llegado a nuestros días. CALVO RUATA, J. I. y LOZANO LÓPEZ, J. C., Op. cit.

71 De principios del siglo XVIII y del que solamente se conserva la traza: un arco de proscenio rematado por ángeles escorzados y roleos vegetales abre una sencilla escena eucarística, erigida sobre doble basamento y articulada mediante arcos-bastidores de escueto motivo angelical, que convergen -guiándose por líneas de tierra; a la manera de toscas escenografías- hacia un ingenuo fondo de altar. El diseño puede consultarse en: FERNÁNDEZ GRACIA, R., «Documentación del Archivo Diocesano de Pamplona para el estudio de la Historia del Arte navarro», Príncipe de Viana, 231 (2004), pp. 100 y 104.

72 Provisto de una multiplicidad de bastidores, se decora con fingidas arquitecturas y escenas de la Pasión y Muerte de Jesucristo. Obrado en la segunda mitad del siglo XVII, nada se conoce sobre su autor, de tardía filiación manierista, torpe en la figuración y en la resolución perspectívica.

73 ESTEBAN LORENTE, J. F., «La capilla de San Marcos y el monumento de Semana Santa de La Seo de Zaragoza», Cuadernos de Investigación. Geografía e Historia, T. 2., Fasc. 1 (1976), pp. 97-103. 
de la perspectiva), precedida por una grada de nueve peldaños. Sigue a este espacio, en precipitado ritmo, una gradería de tres tramos flanqueada por columnas en resalte, con sucesión de cúpulas ovales corregidas ilusionísticamente; todo el conjunto converge hacia el altar central, a cuya espalda aún se simulan pictóricamente cuatro nuevos módulos. El resultado es excepcional, evocando vívidamente la soberbia perspectiva y efectos correctores de la Scala Regia de San Pedro en Vaticano.

La última obra a reseñar merece, sin duda, el calificativo de soberbia. No en vano su autor, el pintor Antonio Viladomat, fue considerado por Mengs «el mejor de España en su tiempo» ${ }^{74}$. La afinidad de este Monumento, ejecutado en 1735-1736 para la Catedral de Barcelona, con la obra del gran maestro del ilusionismo pictórico Andrea del Pozzo o con la del revolucionario escenógrafo Ferdinando Galli Bibiena, a quien debió conocer durante su estancia en Cataluña (en calidad de maestro de ceremonias de la deslumbrante corte del Archiduque don Carlos), parece evidente; de hecho, puede juzgarse la concreción arquitectónica (aunque incorpore perspectivas pintadas) de una fastuosa escenografía del gran maestro boloñés. Las anotaciones marginales del diseño así lo certifican, por cuanto reproducen las indicaciones de una de las láminas del tratado de perspectiva del italiano (L'architettura civile presentata sulla geometria e ridotta alle prospettive; 1711$)^{75}$. El monumento, que sirve igualmente a la celebración de las Cuarenta Horas ${ }^{76}$, se levanta sobre un potente basamento, vencido por gradas en su frente principal, que flanquean cuerpos avanzados de órdenes columnarios coronados por figuras alegóricas y pares de roleos; dos ampulosos arcos, conectados por un atrio descubierto, permiten acceder a la rotonda principal, que acoge un imponente sagrario de estructura elocuentemente tumular.

74 CEÁN BERMÚDEZ, J. A., Op. cit., T. 5, p. 236.

75 BOSCH i BALLBONA, J. y DORICO, C., «El Monument de Setmana Santa de la Catedral de Barcelona, de 1735», D'Art, 17-18 (1992), pp. 253-260.

76 MERCADER SAAVEDRA, S., «Descubiertas las esculturas del antiguo Monumento de Semana Santa de la Catedral De Barcelona (1735)», en DE LA PEÑA, C. et alii (eds.), Congreso Internacional Imagen y Apariencia, Murcia Universidad de Murcia, 2008, p. 5. 
